\title{
Effect of Medicinal Plant Extract Incorporated Carrageenan Based Films on Shelf-Life of Chicken Breast Meat
}

\author{
Kuk-Hwan Seol ${ }^{1}$, Beom-Jin Joo², Hyoun Wook Kim¹, Oun-Ki Chang ${ }^{1}$, Jun-Sang Ham¹, \\ Mi-Hwa Oh ${ }^{1}$, Beom-Young Park ${ }^{1}$, and Mooha Lee* \\ Department of Food and Animal Biotechnology, Research Institute for Agriculture and Life Science, \\ Seoul National University, Seoul 151-921, Korea \\ ${ }^{1}$ National Institute of Animal Science, Rural Development Administration, Suwon 441-706, Korea \\ ${ }^{2}$ Beverage Frozen Indulgence Design Meal Product and Technology Center, Pulmuone Holdings, Seoul 153-035, Korea
}

\begin{abstract}
This study was performed to examine the possibility of water extracts for several medicinal plants, such as Amomum tsaoko, Alpinia oxyphylla, and Citrus unshiu, as an active packaging ingredient for prevention of lipid oxidation. Chicken breast meats were packed with medicinal plant extracts incorporated carrageenan based films and their physico-chemical and microbial properties during storage at $5^{\circ} \mathrm{C}$ were investigated. In chicken meat samples packed with $A$. tsao-ko (TF) or $A$. oxyphylla (OF) extract incorporated carrageenan based films, $\mathrm{pH}$ value, thiobarbituric acid reactive substances (TBARS), and the population of total microbes were significantly lower than those of the negative control (film of no extract was incorporated, $\mathrm{CF})$ after $5 \mathrm{~d}$ of storage $(p<0.05)$. Especially, TBARS value of TF $(0.12 \pm 0.01 \mathrm{mg}$ malonaldehyde/ $\mathrm{kg}$ meat $)$ was significantly lower than chicken meat samples packed with positive control (ascorbic acid incorporated film, AF, $0.16 \pm 0.01$ $\mathrm{mg}$ malonaldehyde $/ \mathrm{kg}$ meat) at $3 \mathrm{~d}$ of storage, and it means TF has enough antioxidative activity to prevent the lipid oxidation of chicken meat. However, there was no consistent effect on VBN values of chicken meats packed with medicinal plant extracts incorporated films during storage. Based on the obtained results, it is considered that $A$. tsao-ko extract has potential for being used as a natural antioxidant ingredient in active packaging areas.
\end{abstract}

Key words: chicken, medicinal plant, carrageenan based film, TBARS, microorganisms

\section{Introduction}

In many countries, medicinal plants have traditionally played a major role in the management of human health and are still playing an active role in the health care, in example, digestive medicinal plants pharmacologically stimulate the exercise of stomach and secretion of digestive juice which helping digestion and absorption. They are generally recognized as safe (GRAS), and contain essential oil and phenolic compounds which have various biological activities, abundantly. As synthetic functional food ingredient exist health and ecological concerns, natural ingredients have become an ecologically important alternative to synthetic ingredients. In the study of Shagidi and Wanasundara (1992), most of antioxidant poten-

*Corresponding author: Mooha Lee, Department of Food and Animal Biotechnology, Research Institute for Agriculture and Life Science, Seoul National University, Seoul 151-921, Korea. Tel: 82-2-880-4820, Fax: 82-2-873-4804, E-mail: moohalee@snu.ac.kr tials in medicinal plants are due to the redox properties of phenolic compounds that allow them to act as reducing agents, hydrogen donators and free radicals quenchers. A great number of medicinal plants have been tested for their antioxidant activities and results have shown that raw extracts or isolated pure compounds from them were more effective antioxidants in vitro than BHA, BHT or vitamin E (Gordon and Weng, 1992; Gu and Weng, 2001; Pyo et al., 2004).

Currently, with the recent increase in ecological concerns, one of the newest research trends has focused on the incorporation of bioactive natural extracts into dietary polymer-based material, such as protein/starch based films. Polysaccharides have been used for edible films most frequently because of their excellent film-forming properties derived from cellulose, starch, alginate, and their mixtures (Durango et al., 2006). Incorporation of plant extracts as antioxidant agents into edible film could create packaging with antioxidant-like properties (Gomez-Estaca et al., 2009; Gomez-Guillen et al., 2007; Siripatrawan and Harte, 
2010), and such a package can be used to inhibit or reduce oxidative degradation of the food inside.

So, this study was performed to examine the possibility of water extracts of several medicinal plants, such as Amomum tsao-ko, Alpinia oxyphylla, and Citrus unshiu Markovich, as an active packaging ingredient. In this study, we examined physico-chemical and microbial changes of chicken breast meats packed with carrageenan based films containing medicinal plant extracts during cold storage.

\section{Materials and Methods}

\section{Materials}

Dried Black cardamom (Alpinia oxyphylla MIQ.), Tsaoko (Amomum tsao-ko CREVOST et LEM), and Satsuma mandarin peel (Citrus unshiu Marcovich) were purchased from domestic oriental medicine clinic. K-carrageenan (99.9\%) was purchased from MSC Co. (Yangsan, Korea). Thiobarbituric acid, EDTA (E-5134), and potassium sorbate (S1751) were purchased from sigma chemical Co. (Sigma, USA), and all other chemicals and solvents used were commercially available analytical grade.

\section{Preparation of carrageenan based film with medic- inal plant extracts}

Medicinal plants were extracted with 10 folds of distilled water in a $100^{\circ} \mathrm{C}$ water bath (JEIO TECH CW-30G, Korea) for $1 \mathrm{~h}$, subsequently filtered and lyophilized (Ilshin FD8505, Korea). Carrageenan based films were prepared by the methods of Pavlath et al. (1999) and Cha et al. (2002) with $\kappa$-carrageenan. $\kappa$-carrageenan solutions $(2 \%$ $\mathrm{w} / \mathrm{w}$ ) were prepared by dispersing the polysaccharide in distilled water under continuous stirring and heating in the presence of $1.5 \%$ plasticizer ( $50 \%$ polyethylene glycol $+50 \%$ glycerol) at $90^{\circ} \mathrm{C}$ in a water bath for $40 \mathrm{~min}$ with constant stirring. Durango et al. (2006) reported that the addition of plasticizing agent such as glycerol and sorbitol into the film is used frequently to reduce the intermolecular forces and increase the mobility of the polymeric chains, resulting in a better flexibility. Then, solutions were cooled to $60^{\circ} \mathrm{C}$ and $1 \%$ of medicinal plant extracts per $\mathrm{g}$ of $\mathrm{K}$-carrageenan were added with constant stirring. K-carrageenan solutions without any extract (CF) for the negative control, and containing $1 \%$ of ascorbic acid (AF) for the positive control were also prepared. The $50 \mathrm{~mL}$ of carrageenan film solution was spread on polyacrylic plates $(10 \times 10 \mathrm{~cm})$ with a $5 \mathrm{~mm}$ spacer. The solution on the plate was dried at $40^{\circ} \mathrm{C}$ for $24 \mathrm{~h}$. After cooling to room temperature, each film was carefully peeled from the plate and stored in a polyethylene bag for further experiment.

\section{Effects of carrageenan based film packaging on shelf-life of chicken breast meat}

Fresh chicken breast meat was purchased from domestic market. Each piece of breast meat was wrapped with carrageenan based film and packed in low-density polyethylene (LDPE) bags, then stored at $5^{\circ} \mathrm{C}$ refrigerator for $5 \mathrm{~d}$. The $\mathrm{pH}$ value, thiobarbituric acid reacting substances (TBARS), volatile basic nitrogen (VBN), and total microbes of raw meat and packed samples were measured on 0 (raw meat), 1, 3, and $5 \mathrm{~d}$ of storage. The $\mathrm{pH}$ of chicken breast meat was determined with digital $\mathrm{pH}$ meter (4 Star, Orion, USA) equipped with a combined glass electrode. On $5 \mathrm{~g}$ of breast meat was homogenized with $20 \mathrm{~mL}$ distilled water using Ultra-Turrex T25 tissue homogenizer (Janke and Kenkel, IKA, Labor Tecnik, Germany) for 1 $\mathrm{min}$. Five gram of patty was homogenized with $45 \mathrm{~mL}$ of buffered peptone water and serially diluted. Pour plate methods in duplicate were used to analyze the total microbes of patties. TBARS was analyzed by Witt et al. (1970) with slight modification. Briefly, $5 \mathrm{~g}$ of meat sample was added to $45 \mathrm{~mL}$ of $20 \%$ trichloroacetic acid (in 2 $M$ phosphate solution) and homogenized using Ultra-Turrex T25 tissue homogenizer (Janke and Kenkel, IKA, Labor Tecnik, Germany), and the solution was filtered through Whatman No. 1 filter paper. After mixing $5 \mathrm{~mL}$ of filtrate with $5 \mathrm{~mL}$ of 2-thiobarbituric acid $(0.005 \mathrm{M}$ in water) in test tube, the test tubes were kept at room temperature in the dark for $15 \mathrm{~h}$, and measured the absorbance at $531 \mathrm{~nm}$ using spectrophotometer (X-ma 1000, Human Co., Korea). VBN was measured by modified micro-diffusion assay according to the Standards for Processing \& Ingredient Specifications of Livestock Product method (SPISLP, 2011).

$$
\operatorname{VBN}(\mathrm{mg} \%)=[(\mathrm{a}-\mathrm{b}) \times(0.14 \times \mathrm{f} \times 100 \times \mathrm{d}) / \mathrm{S}]
$$

where $\mathrm{a}$ is the sample titer, $\mathrm{b}$ is the blank titer, $\mathrm{f}$ is a reagent factor, $d$ is the sample dilution, and $S$ is sample weight (g). Pour plate methods in duplicate were used to analyze the total microbes of breast meat.

\section{Statistical analysis}

All experiments were repeated three times and the statistical analysis was performed with the SAS program for Windows V9.2 (SAS Institute, Cary, NC, USA). ANOVA with Duncan's multiple range test was carried out to ana- 
lyze the significant differences among the treatments $(p<0.05)$.

\section{Results and Discussion}

\section{Change of physicochemical properties of chicken breast meat during cold storage}

The effect of medicinal plant extracts incorporated carrageenan based film packaging on the $\mathrm{pH}$ value of chicken breast meat held under chilled conditions is shown in Table 1. $\mathrm{pH}$ is one of the main factors which can influence the physicochemical properties of meat, such as water holding capacity (WHC), color, and cooking loss. The $\mathrm{pH}$ values are increasing during storage period, due to the accumulation of metabolites by bacterial action in meat and deaminations of proteins (Jay, 1996). In this study, although there was no significance, $\mathrm{pH}$ values of chicken breast meats packed with medicinal plant extracts incorporated films (OF, TF, and UF) showed decreasing tendency as storage period increased, while control film packed chicken breast meat (CF) increased significantly during storage period. The lower $\mathrm{pH}$ values of chicken breast meats packed with medicinal plant extracts incorporated films may attributed by the low $\mathrm{pH}$ values of medicinal plant extracts (A. tsao-ko; 5.25, A. oxyphylla; 5.12, C. unshiu; 4.72), as reported in our previous study which used same volume of medicinal plants and extraction method (Seol et al., 2011). The $\mathrm{pH}$ values of breast meat packed with ascorbic acid incorporated film (AF) was significantly lower than others after $1 \mathrm{~d}$ of storage $(p<0.05)$, and the $\mathrm{pH}$ values of all breast meat packed with treated films were significantly lower than that of $\mathrm{CF}$ after $1 \mathrm{~d}$ of storage $(p<0.05)$. However, the species of medicinal plant extract didnot affect consistently to the $\mathrm{pH}$ values of breast meat during the overall storage period. Mansour and Khalil (2000) reported that there was no $\mathrm{pH}$ difference between controls and antioxidants added samples over 35 days of chilled storage, however, the $\mathrm{pH}$ values of all patties increased significantly during storage. McCarthy et al. (2001) and Sahoo (1995) reported similar findings in pork patties and in ground buffalo meat containing BHA/BHT antioxidants during refrigerated and frozen storage, respectively.

The change of TBARS value of chicken breast meat packed with medicinal plant extract incorporated films was shown in Table 2. As storage period was increased, TBARS values of all tested breast meats were increased, significantly $(p<0.05)$. Chicken breast meats packed with A. oxyphylla or A. tsao-ko extract incorporated films (OF or TF) showed significantly lower TBARS values than those of CF until $3 \mathrm{~d}$ after storage, however, they had higher TBARS values than those of AF at the end of storage $(p<0.05)$. Between the tested medicinal plant extract incorporated films during storage period, TF showed the highest antioxidant potential, and this result is corresponding with our previous report (Seol et al., 2011), which showed the highest antioxidant potential of $A$. tsao-ko extract in pork patties. Bolumar et al. (2011) monitored the lipid oxidation as TBARS throughout the storage period of $25 \mathrm{~d}$ at the surface and the inner part of chicken breast patties packed in standard packaging or in antioxidant active packaging, and reported the decrease in the level of lipid oxidation in the surface and inner part packed with active packaging tended to be lower than in the control patties, and those results corresponding with this study.

VBN is related with protein breakdown, which is associated with the amino acid decarboxylase activity of microorganisms during storage (Ahn et al., 2000; Egan et $a l ., 1981$ ), and generally could be used as a quality indicator for fish products (Lin et al., 1995; Ohashi et al., 1991). Changes in VBN value of chicken breast meat

Table 1. The change of $\mathrm{pH}$ of chicken breasts packed with various films

\begin{tabular}{|c|c|c|c|c|}
\hline $\begin{array}{ll}\text { Treatments* } & \text { Storage }(\mathrm{d}) \\
\end{array}$ & $\begin{array}{c}0 \\
\text { (Raw meat) }\end{array}$ & 1 & 3 & 5 \\
\hline $\mathrm{CF}$ & $6.36 \pm 0.09^{b}$ & $6.29 \pm 0.01^{\mathrm{bA}}$ & $6.38 \pm 0.00^{\mathrm{bA}}$ & $6.51 \pm 0.00^{\mathrm{aA}}$ \\
\hline $\mathrm{AF}$ & $6.36 \pm 0.09^{\mathrm{a}}$ & $5.61 \pm 0.00^{\mathrm{bD}}$ & $5.30 \pm 0.01^{\mathrm{cE}}$ & $5.11 \pm 0.00^{\mathrm{dE}}$ \\
\hline OF & $6.36 \pm 0.09^{\mathrm{a}}$ & $6.27 \pm 0.02^{\mathrm{abAB}}$ & $6.10 \pm 0.00^{\mathrm{cD}}$ & $6.20 \pm 0.01^{\mathrm{bcB}}$ \\
\hline $\mathrm{TF}$ & $6.36 \pm 0.09^{\mathrm{a}}$ & $6.13 \pm 0.01^{\mathrm{bB}}$ & $6.31 \pm 0.00^{\mathrm{aB}}$ & $6.12 \pm 0.01^{\mathrm{bD}}$ \\
\hline UF & $6.36 \pm 0.09^{\mathrm{a}}$ & $6.11 \pm 0.00^{\mathrm{bC}}$ & $6.29 \pm 0.00^{\mathrm{aC}}$ & $6.15 \pm 0.00^{\mathrm{bC}}$ \\
\hline
\end{tabular}

${ }^{*} \mathrm{CF}$, Chicken breast samples packed with control film; AF, Chicken breast samples packed with ascorbic acid incorporated film; OF, Chicken breast samples packed with $A$. oxyphylla extract incorporated film; TF, Chicken breast samples packed with $A$. tsao-ko extract incorporated film; UF, Chicken breast samples packed with C. unshiu extract incorporated film.

Values are mean \pm SD.

${ }^{\mathrm{a}-\mathrm{d}}$ Means in the same row with different letters are significantly different $(p<0.05)$.

${ }^{\mathrm{A}-\mathrm{E}}$ Means in the same column with different letters are significantly different $(p<0.05)$. 
Table 2. The change of thiobarbituric acid reacting substances (TBARS) value of chicken breasts packed with various films

(mg malonaldehyde/kg meat)

\begin{tabular}{ccccc}
\hline \hline Storage (d) & 0 & 1 & 3 & 5 \\
Treatments $^{\text {I) }}$ & $($ Raw meat) & & $0.20 \pm 0.01^{\mathrm{bA}}$ & $0.24 \pm 0.01^{\mathrm{aA}}$ \\
CF & $0.04 \pm 0.01^{\mathrm{d}}$ & $0.13 \pm 0.01^{\mathrm{cA}}$ & $0.16 \pm 0.01^{\mathrm{bB}}$ & $0.18 \pm 0.03^{\mathrm{aB}}$ \\
AF & $0.04 \pm 0.01^{\mathrm{d}}$ & $0.11 \pm 0.00^{\mathrm{cAB}}$ & $0.15 \pm 0.01^{\mathrm{bC}}$ & $0.22 \pm 0.04^{\mathrm{aAB}}$ \\
OF & $0.04 \pm 0.01^{\mathrm{d}}$ & $0.10 \pm 0.02^{\mathrm{cB}}$ & $0.12 \pm 0.01^{\mathrm{bD}}$ & $0.19 \pm 0.03^{\mathrm{aAB}}$ \\
TF & $0.04 \pm 0.01^{\mathrm{d}}$ & $0.07 \pm 0.01^{\mathrm{cC}}$ & $0.16 \pm 0.01^{\mathrm{bB}}$ & $0.20 \pm 0.03^{\mathrm{aAB}}$ \\
UF & $0.04 \pm 0.01^{\mathrm{d}}$ & $0.09 \pm 0.00^{\mathrm{cB}}$ & \\
\hline
\end{tabular}

${ }^{1)} \mathrm{CF}$, Chicken breast samples packed with control film; AF, Chicken breast samples packed with ascorbic acid incorporated film; OF, Chicken breast samples packed with $A$. oxyphylla extract incorporated film; TF, Chicken breast samples packed with $A$. tsao-ko extract incorporated film; UF, Chicken breast samples packed with C. unshiu extract incorporated film.

Values are mean $\pm \mathrm{SD}$.

${ }^{\mathrm{a}-\mathrm{d}}$ Means in the same row with different letters are significantly different $(p<0.05)$.

${ }^{\text {A-D }}$ Means in the same column with different letters are significantly different $(p<0.05)$.

Table 3. The change of volatile basic nitrogen (VBN) value of chicken breasts packed with various films

$(\mathrm{mg} \%)$

\begin{tabular}{ccccc}
\hline \hline Storage (d) & $\begin{array}{c}0 \\
\text { (Raw meat) }\end{array}$ & 1 & 3 & 5 \\
\hline CF & $13.97 \pm 2.46^{\mathrm{c}}$ & $18.35 \pm 7.63^{\mathrm{bc}}$ & $27.64 \pm 1.29^{\mathrm{aA}}$ & $23.53 \pm 1.68^{\mathrm{abC}}$ \\
AF & $13.97 \pm 2.46^{\mathrm{b}}$ & $16.14 \pm 5.52^{\mathrm{b}}$ & $25.59 \pm 3.56^{\mathrm{aAB}}$ & $25.59 \pm 0.65^{\mathrm{aB}}$ \\
OF & $13.97 \pm 2.46^{\mathrm{c}}$ & $17.93 \pm 7.53^{\mathrm{bc}}$ & $26.71 \pm 0.32^{\mathrm{aAB}}$ & $24.28 \pm 0.86^{\mathrm{abBC}}$ \\
TF & $13.97 \pm 2.46^{\mathrm{b}}$ & $14.79 \pm 5.99^{\mathrm{b}}$ & $24.84 \pm 0.65^{\mathrm{aAB}}$ & $30.26 \pm 0.56^{\mathrm{aA}}$ \\
UF & $13.97 \pm 2.46^{\mathrm{b}}$ & $21.40 \pm 8.13^{\mathrm{a}}$ & $23.53 \pm 0.00^{\mathrm{aB}}$ & $23.53 \pm 0.00^{\mathrm{aC}}$ \\
\hline
\end{tabular}

${ }^{1)} \mathrm{CF}$, Chicken breast samples packed with control film; AF, Chicken breast samples packed with ascorbic acid incorporated film; OF, Chicken breast samples packed with $A$. oxyphylla extract incorporated film; TF, Chicken breast samples packed with $A$. tsao-ko extract incorporated film; UF, Chicken breast samples packed with C. unshiu extract incorporated film.

Values are mean $\pm \mathrm{SD}$.

${ }^{\mathrm{a}-\mathrm{c}}$ Means in the same row with different letters are significantly different $(p<0.05)$.

${ }^{\mathrm{A}-\mathrm{C}}$ Means in the same column with different letters are significantly different $(p<0.05)$.

packed with medicinal plant extract incorporated films during storage are shown in Table 3. The VBN values of tested samples were increased during chilled storage; however, there was no consistent tendency between treatments. This result is not consistent with the results of Wang (2000), who suggested that antioxidant materials added samples had significantly lower VBN values.

\section{Change of microbial properties of chicken breast meat during cold storage}

The effect of medicinal plant extract incorporated film packaging on total microbes during chilled storage of chicken breast meat is shown in Table 4. In general, chicken breast meats packed with carrageenan based films significantly increased in total plate counts (TPC) as the storage period increased. After $5 \mathrm{~d}$ of storage, there

Table 4. The change of total microbes of chicken breasts packed with various films

\begin{tabular}{|c|c|c|c|c|}
\hline $\begin{array}{ll}\text { Treatments }^{1)} & \text { Storage (d) } \\
\end{array}$ & $\begin{array}{c}0 \\
\text { (Raw meat) }\end{array}$ & 1 & 3 & 5 \\
\hline $\mathrm{CF}$ & $2.98 \pm 0.34^{\mathrm{c}}$ & $2.74 \pm 0.17^{\mathrm{cAB}}$ & $4.02 \pm 0.21^{\mathrm{bB}}$ & $5.02 \pm 0.12^{\mathrm{aA}}$ \\
\hline $\mathrm{AF}$ & $2.98 \pm 0.34$ & $2.67 \pm 0.51^{\mathrm{B}}$ & $2.76 \pm 0.21^{\mathrm{D}}$ & $2.33 \pm 0.58^{\mathrm{D}}$ \\
\hline OF & $2.98 \pm 0.34^{\mathrm{b}}$ & $3.20 \pm 0.21^{\mathrm{abA}}$ & $3.16 \pm 0.23^{\mathrm{abC}}$ & $3.67 \pm 0.11^{\mathrm{aC}}$ \\
\hline $\mathrm{TF}$ & $2.98 \pm 0.34^{\mathrm{b}}$ & $2.99 \pm 0.38^{\mathrm{cAB}}$ & $4.90 \pm 0.11^{\mathrm{aA}}$ & $4.13 \pm 0.27^{\mathrm{bB}}$ \\
\hline UF & $2.98 \pm 0.34^{\mathrm{c}}$ & $3.08 \pm 0.25^{\mathrm{bAB}}$ & $3.03 \pm 0.13^{\mathrm{bC}}$ & $4.06 \pm 0.16^{\mathrm{aB}}$ \\
\hline
\end{tabular}

${ }^{1)} \mathrm{CF}$, Chicken breast samples packed with control film; AF, Chicken breast samples packed with ascorbic acid incorporated film; OF, Chicken breast samples packed with $A$. oxyphylla extract incorporated film; TF, Chicken breast samples packed with $A$. tsao-ko extract incorporated film; UF, Chicken breast samples packed with C. unshiu extract incorporated film.

Values are mean $\pm \mathrm{SD}$.

${ }^{\mathrm{a}-\mathrm{c}}$ Means in the same row with different letters are significantly different $(p<0.05)$.

${ }^{\text {A-D }}$ Means in the same column with different letters are significantly different $(p<0.05)$. 
was significant difference between medicinal plant extract incorporated film packed and control film packed breast meats $(p<0.05)$. This result is consistent with the result of Park et al. (2005) who reported the addition of medicinal plant mixture extract to marinated beef inhibited the microbial growth during chilled storage.

Medicinal plant extracts tested in this study showed antioxidative effect when incorporated in carrageenan based film by inhibiting the lipid oxidation of chicken breast meat. Thus, tested medicinal plant extracts has possibility to develop as natural antioxidant ingredients for active packaging, and need to study more about their utilization as an alternative of synthetic chemicals.

\section{References}

1. Ahn, D. U., Jo, C., Du, M., Olson, D. G., and Nam, K. C. (2000) Quality characteristics of pork patties irradiated and stored in different packaging and storage conditions. Meat Sci. 56, 203-209.

2. Bolumar, T., Andersen, M. L., and Orlien, V. (2011) Antioxidant active packaging for chicken meat processed by high pressure treatment. Food Chem. 129, 1406-1412.

3. Cha, D. S., Choi, J. H., Chinnan, M. S., and Park, H. J. (2002) antimicrobial films based on Na-alginate and K-carrageenan. Lebenson. Wiss. Technol. 35, 715-719.

4. Durango, A. M., Soares, N. F. F., Benevides, S., Teixeira, J., Carvalho, M., Wobeto, C., and Andrade, N. J. (2006) Development and evaluation of an edible antimicrobial film based on yam starch and chitosan. Packag. Technol. Sci., 19, 5559.

5. Egan, H., Kirk, R. S., and Sawyer, R. (1981) Pearson's chemical analysis of foods $\left(8^{\text {th }}\right.$ ed.), Essex: Longman scientific and Technical, UK. pp. 185-185.

6. Gomez-Estaca, J., Gimenz, B., Montero, P., and GomezGuillen, M. C. (2009) Incorporation of antioxidant borage extract into edible films based on sole skin gelation or a commercial fish gelatin. J. Food Eng. 92, 78-85.

7. Gomez-Guillen, M. C., Ihl, M., Bifani, V., Silva, A., and Montero, P. (2007) Edible films made from tuna-fish gelatin with antioxidant extracts of two different murta ecotypes leaves (Ugni molinae Turcz). Food Hydrocoll. 21, 11331143.

8. Gordon, M. H. and Weng, X. C. (1992) Antioxidant properties of extracts from tanshen (Salvia miltiorrhiza Bunge). Food Chem. 44, 119-122.

9. Gu, L. W. and Weng, X. C. (2001) Antioxidant activity and components of Salvia plebeian R. Br. - a Chinese herb. Food Chem. 73, 299-305.

10. Jay, J. M. (1996) Antioxidants. In: Modern food microbiol- ogy, 4th ed., CBS Publishers and Distributors, New Delhi, pp. 265-266.

11. Lin, L. C., Chen, C. M., and Yen, G. C. (1995) Relationship between biogenic amine contents and quality of lean meat of Chinese-style sausage prepared from pork ham stored at different temperature. Food Sci. (Taiwan) 22, 448-460.

12. Mansour, E. H. and Khalil, A. H. (2000) Evaluation of antioxidant activity of some plant extracts and the application to ground beef patties. Food Chem. 69, 135-141.

13. McCarthy, T. L., Kerry, J. F., Lynch, P. B., and Buckley, D. J. (2001) Evaluation of antioxidant potential of natural foods plant extract as compared with synthetic antioxidants and vitamin E in raw and cooked pork patties. Meat Sci. 57, 4552.

14. Ohashi, E., Okamoto, M., Ozawa, A., and Fugita, T. (1991) Characterization of common squid using several freshness indicators. J. Food Sci. 56, 161-163.

15. Park, J. G., Her, J. H., Li, S. Y., Cho, S. H., Youn, S. K., Choi, J. S., Park, S. M., and Ahn, D. H. (2005) Study on the improvement of storage property and quality in the traditional seasoning beef containing medicinal plant herb extracts. J. Korean Soc. Food Sci. Nutr. 34, 113-119.

16. Pavlath, A. E., Gossett, C., Camirand, W., and Rovertson, G. H. (1999) Ionomeric films of alginic acid. J. Food Sci. 4, 6163.

17. Pyo, Y. H., Lee, T. C., Logendrac, L., and Rosen, R. T. (2004) Antioxidant activity and phenolic compounds of Swiss chard (Beta vulgaris subspecies cycla) extracts. Food Chem. 85, 19-26.

18. Sahoo, J. (1995) Effect of preblending and vacuum packaging on the quality of ground buffalo meat. Ph.D. thesis, Deemed Univ., IVRI, Izatnagar, India.

19. Shagidi, F. and Wanasundara, P. K. (1992) Phenolic antioxidants. Crit. Rev. Food Sci. Nutr. 32, 67-103.

20. Siripatrawan, U. and Harte, B. R. (2010) Physical properties and antioxidant activity of an active film from chitosan incorporated with green tea extract. Food Hydrocoll. 24, 770-775.

21. SPISLP (Standard for Processing \& Ingredient Specifications of Livestock Product) (2011) Animal, Plant and Fisheries Quarantine and Inspection Agency (APFQIA), Korea, pp. 300-302.

22. Wang, F. S. (2000) Effects of three preservative agents on the shelf life of vacuum packaged Chinese-style sausage stored at $20^{\circ}$ C. Meat Sci. 56, 67-71.

23. Witt, V. C., Krouze, G. F., and Bailey, M. E. (1970) A new extraction method for determining 2-thiobarbituric acid values of pork and beef during storage. J. Food Sci. 35, 482485.

(Received 2012.10.19/Revised 2013.1.11/Accepted 2013.1.18) 